\title{
Neonatal Cholestasis due to Plasmodium Vivax Malaria
}

\author{
S. D. Sharma • R. K. Gupta • Alok Kumar Goyal • Anurag Sarna
}

Received: 14 June 2012 / Accepted: 25 March 2013 /Published online: 25 April 2013

(C) Dr. K C Chaudhuri Foundation 2013

To the Editor: Congenital Malaria $(\mathrm{CM})$ is a rare disease even in endemic areas $[1,2]$. Cholestatic jaundice due to $\mathrm{CM}$ is very rare and it is almost always associated with P. falciparum infection [3]. We are reporting a case of CM presenting as cholestatic jaundice due to $P$. vivax infection. To the best of our knowledge, no case has been reported from India till date.

A 1-mo-old female infant came with fever for $5 \mathrm{~d}$, jaundice and clay stools for $3 \mathrm{~d}$, feeding difficulty and lethargy. Antenatal history was uneventful.

On physical examination pallor was present. The infant had weight of $5.2 \mathrm{~kg}$ and was icteric and had a palpable liver $3 \mathrm{~cm}$ below right costal margin (span $6.5 \mathrm{~cm}$ ) and spleen $3 \mathrm{~cm}$ below left costal margin, firm and non tender. The stools were clay colored and urine was dark yellow.

Laboratory investigations showed hemoglobin $7.2 \mathrm{~g} / \mathrm{dL}$, platelet counts- 73000, TLC - 15,200 with N34\%, L66\%. Reticulocyte counts were $0.2 \%$. Peripheral blood film (PBF) showed microcytic hypochromic anemia with schizonts of $P$. vivax. Serum bilirubin was $17.8 \mathrm{mg} / \mathrm{dL}$ (conjugated $7.8 \mathrm{mg} / \mathrm{dL}$ ). SGOT, SGPT, GGT, Alkaline phosphatase were 1674, 1993, 125, 422 IU/L, respectively. The Australia antigen, IgM-anti HAV, and Anti-HEV were negative.

A diagnosis of " $P$. vivax malaria with neonatal cholestasis" was made and IV Artesunate was started. During $5 \mathrm{~d}$ of treatment the icterus and fever disappeared and serum bilirubin came to $4.1 \mathrm{mg} / \mathrm{dL}$ (direct $1.2 \mathrm{mg} / \mathrm{dL}$ ). The SGPT, SGOT were 26 and $72 \mathrm{U} / \mathrm{L}$ respectively. PBF showed absence of parasite.

S. D. Sharma $\cdot$ R. K. Gupta · A. K. Goyal • A. Sarna Department of Pediatrics Medicine, Sir Padampat Mother \& Child Health Institute, SMS Medical College, Jaipur, India

A. K. Goyal $(\bowtie)$

A-239, Behind Reliance Fresh, 80 feet Road, Mahesh Nagar, Jaipur 302015, India

e-mail: dralok_goyal@yahoo.com
$\mathrm{CM}$ is an uncommon cause of fever, splenomegaly, and anemia in infants [4]. The diagnosis can easily be missed if it is not considered. In clinical setting daily examination of thick and thin smears/malaria rapid diagnosis test should be done for evidence of intracellular parasites. The disease most commonly presents during the first $4 \mathrm{wk}$ of life but its onset can be delayed for few months. Neonatal Cholestasis due to congenital malaria improves in $1 \mathrm{wk}$ while neonatal cholestasis due to other causes may take 4-6 wk [3,5].

\section{References}

1. Logie DE, McGregor IA. Acute malaria in newborn infants. Br Med J. 1970;3:404-5.

2. Barnett ED. Malaria. In: Feigin RD, Demmler- Harrison GJ, Cherry JD, Kaplan SL, eds. Feigin and Cherry's Textbook of Pediatric Infectious Diseases. 6th ed. Philadelphia: Saunders Elsevier; 2009. pp. 2899-920.

3. Hazra BR, Chowdhury RS, Saha SK, Ghosh MB, Mazumder AK. Changing scenario of malaria: A study at Calcutta. Indian J Malariol. 1998;35:111-6.

4. John CC, Krause PJ. Malaria (Plasmodium). In: Kliegman RM, Stanton BF, Geme JWS, Schor NF, Behrman RE, eds. Nelson Textbook of Pediatrics. 19th ed. Philadelphia: Elsevier Saunders; 2011. pp. 1198-207.

5. Maldonado YA. Less common protozoan and helminth infections. In: Remington JS, Klein JO, Wilson CB, Nizet V, Maldonado YA, eds. Infectious Diseases of the Fetus and Newborn Infant. 7th ed. Philadelphia: Saunders Elsevier; 2011. pp. 1046-51. 